DOI: https://doi.org/10.47405/mjssh.v6i4.740

\begin{tabular}{|c|c|}
\hline$x_{1}=$ & Malaysian Journal of Social Sciences and Humanities (MJSSH) \\
\hline $\begin{array}{l}\text { Malaysian Journal of } \\
\text { Social cciences and }\end{array}$ & Volume 6, Issue 4, April 2021 \\
\hline (MJ-SSH) & e-ISSN : 2504-8562 \\
\hline & $\begin{array}{l}\text { Journal home page: } \\
\text { www.msocialsciences.com }\end{array}$ \\
\hline
\end{tabular}

\title{
Amalan Kepimpinan Instruksional Guru Besar dan Hubungannya dengan Tanggapan Sokongan Organisasi Guru-Guru Sekolah Jenis Kebangsaan Tamil
}

\author{
Anpalakan Vadiappan' ${ }^{1}$, Al-Amin Mydin'1 , Abdul Jalil Ali'1 \\ ${ }_{1}^{1}$ Pusat Pengajian Ilmu Pendidikan, Universiti Sains Malaysia (USM)
}

Correspondence: Anpalakan Vadiappan (anpalakan@student.usm.my)

\begin{abstract}
Abstrak
Kewibawaan pemimpin dan sokongan organisasi merupakan faktor asas kecemerlangan sesebuah organisasi pendidikan. Oleh itu, kepimpinan instruksional dikaji di seluruh dunia dan semakin popular dalam dunia pendidikan. Kementerian Pendidikan Malaysia (KPM) juga telah menyeru agar pemimpin sekolah untuk mengamalkan kepimpinan instruksional sebagai salah satu model dalam menerajui sekolah-sekolah di negara ini. Menyedari akan kepentingan ini, kajian ini dilaksanakan bertujuan untuk memahami amalan kepimpinan instruksional guru besar dan tanggapan sokongan organisasi di Sekolah Jenis Kebangsaan Tamil (SJKT). Kajian ini menggunakan reka bentuk tinjauan jenis kuantitatif yang menggunakan Principal Instructional Management Rating Scale (PIMRS) dan Survey of Perceived Organizational Support (SPOS) untuk mengumpul data. Seramai 210 orang guru terlatih yang berkhidmat di 19 buah SJKT di negeri Pulau Pinang telah mengambil bahagian dalam kajian ini. Data kajian dianalisis menggunakan perisian Statistical Package for Social Sciences (SPSS) versi 26. Dapatan kajian menunjukkan bahawa amalan kepimpinan guru besar dan tanggapan sokongan organisasi guru berada pada tahap tinggi. Ujian-t sampel bebas mendedahkan bahawa terdapat perbezaan dalam amalan kepimpinan instruksional guru besar berdasarkan jantina guru dan lokasi sekolah. Manakala, ujian ANOVA sehala pula tidak menunjukkan sebarang perbezaan berdasarkan umur guru. Seterusnya, tanggapan sokongan organisasi guru SJKT pula, menunjukkan wujud perbezaan skor min dalam jantina guru dan lokasi sekolah. Dapatan ujian korelasi Pearson turut mendedahkan bahawa tidak ada hubungan antara amalan kepimpinan instruksional guru besar dengan tanggapan sokongan organisasi guru-guru SJKT. Secara keseluruhannya, dapat disimpulkan bahawa amalan kepimpinan instruksional guru besar bukan faktor mutlak yang menentukan tanggapan sokongan organisasi guru-guru SJKT negeri Pulau Pinang. Faktor-faktor lain masih berpengaruh dalam menentukan tahap tanggapan sokongan organisasi guru-guru SJKT.
\end{abstract}

Kata kunci: Kepimpinan instruksional, tanggapan sokongan organisasi, Sekolah Jenis Kebangsaan Tamil

\section{Head Teachers' Instructional Leadership Practices and Its Relationship with Teachers' Perceived Organizational Support in National Tamil Primary School}

\begin{abstract}
Instructional leadership and organizational supports are among the success factors of educational organization. Therefore, instructional leadership has been studied worldwide and getting famous in
\end{abstract}


education world. The Ministry of Education of Malaysia also demanded the schools' leaders to adopt instructional leadership as one of the models to lead the schools. Due to this demand, this study aims to explore further instructional leadership practices of head teachers and perceived of organizational support in National Tamil Primary Schools (NTPS). This study uses a quantitative survey design that employed the Principal Instructional Management Rating Scale (PIMRS) and the Survey of Perceived Organizational Support (SPOS) to collect data. A total of 210 trained teachers who serve in 19 NTPS in the state of Penang participated in this study. The study data were analyzed using Statistical Package for Social Sciences (SPSS) version 26. The findings showed that the instructional leadership practices of head teachers and the perceived of organization support are at a high level. An independent sample t-test revealed that there were differences in principals' instructional leadership practices based on teacher gender and school location. Meanwhile, the one-way ANOVA test did not show any differences in principals' instructional leadership practices based on the age of the teachers. Furthermore, the perception of organizational support for NTPS teachers, shows that there is a difference in mean scores in the gender of teachers and school location. The findings of the Pearson correlation test also revealed that there is no relationship between the instructional leadership practices of head teachers with the perception of organizational support of NTPS teachers. This study concludes that the instructional leadership practices of head teachers are not an absolute factor that determines the perceived of organizational support of NTPS teachers in Penang. Many other factors are influencing the perceived of organizational support in NTPS.

Keywords: instructional leadership, perceived organizational support, National Tamil Primary School

\section{Pengenalan}

Menurut Baskaran dan A. Hamid (2020), kecemerlangan sesebuah organisasi pendidikan amat bergantung kepada kewibawaan pemimpin yang menerajuinya. Justeru itu, Kementerian Pendidikan Malaysia (KPM) menyeru agar kesemua pemimpin sekolah seperti guru besar mengamalkan kepimpinan instruksional sebagai salah satu model dalam menerajui sekolah-sekolah di negara ini (Bush et al., 2018). Penggunaan model ini turut disokong oleh Ithnin dan Abdullah (2018). Menurut mereka, jatuh bangun sesebuah sekolah amat bergantung kepada kebolehan pemimpin instruksional yang menerajui organisasi tersebut. Pada masa yang sama, Abd Wahab dan Abdullah (2018) juga bersetuju bahawa perlakuan pemimpin sering dikaitkan dengan kepercayaan guru terhadap organisasi pendidikan. Mereka percaya bahawa pemimpin instruksional mampu melahirkan persekitaran kerja yang kondusif dan sekali gus boleh meningkatkan prestasi sekolah.

Kajian Chong et al. (2019) membuktikan bahawa pemimpin sekolah masih tidak kompeten sebagai seorang pepimpin. Bukan itu sahaja, Bada et al. (2020) juga menyatakan bahawa pemimpin sekolah masih tidak jelas akan tanggungjawab instruksi. Terdahulu, Ithnin dan Abdullah (2018) mendakwa pemimpin sekolah masih mengutamakan tugas pentadbiran berbanding aspek-aspek instruksional. Disebabkan oleh kelemahan pemimpin sekolah dalam aspek ini, beberapa kajian mendapati berlakunya ketidakcekapan mengurus sumber sekolah (Othman, 2016), guru besar kurang berada di sekolah (Hassan et al., 2017), kekurangan pemantauan aktiviti pengajaran dan pembelajaran (PdPc) (Ithnin \& Abdullah, 2018; Hassan et al., 2017) serta ketidakmampuan pemimpin untuk mewujudkan persekitaran kerja yang kondusif (Baskaran \& A. Hamid, 2020). Bada et al. (2020). Dapatan-dapatan sebegini menjejaskan imej pemimpin sekolah di kaca mata masyarakat.

Selain daripada itu, kajian-kajian terdahulu juga turut mendedahkan bahawa guru-guru kurang menerima sokongan di peringkat sekolah (Ambikapathy et al., 2020; Chong et al., 2019; Yong \& Ku Samsu, 2019; Vinathan, 2016; Qadach \& Schechter, 2020). Dapatan ini turut disokong oleh Saleem et al. (2017) yang menyatakan bahawa kekurangan sokongan organisasi mengakibatkan warga sekolah terutamanya para guru menghadapi pelbagai cabaran. Cabaran-cabaran ini telah mengakibatkan sebilangan guru mengalami kemerosotan dalam kesihatan mental (Jose \& Mohd Matore, 2021), kurang efektif (Qadach \& Schechter, 2020), menghadapi beban dan tekanan kerja yang melampau (Seman et 
al., 2021; Kamarudin \& Taat, 2020), kurang bermotivasi (Aminah Jekri \& Han, 2020) dan kurang komitmen kerja (Billy \& Taat, 2020).

\section{Objektif Kajian}

Berdasarkan kepada pernyataan di atas, beberapa objektif kajian telah dibina bagi menjalankan kajian ini. Objektif kajian adalah seperti berikut:

i. Mengenal pasti tahap amalan kepimpinan instruksional guru besar SJKT

ii. Mengenal pasti tahap tanggapan sokongan organisasi guru-guru SJKT

iii. Mengenal pasti perbezaan skor min kepimpinan instruksional guru besar SJKT berdasarkan jantina guru

iv. Mengenal pasti perbezaan skor min tanggapan sokongan organisasi guru-guru SJKT berdasarkan jantina guru

v. Mengenal pasti perbezaan skor min kepimpinan instruksional guru besar SJKT berdasarkan lokasi sekolah

vi. Mengenal pasti perbezaan skor min tanggapan sokongan organisasi guru-guru SJKT berdasarkan lokasi sekolah

vii. Mengenal pasti perbezaan skor min kepimpinan instruksional guru besar SJKT berdasarkan umur guru

viii. Menentukan hubungan antara kepimpinan instruksional guru besar dengan tanggapan sokongan organisasi guru-guru SJKT

\section{Hipotesis Kajian}

Hipotesis kajian adalah seperti berikut:

$\mathrm{H}_{0} 1$ : Tidak terdapat perbezaan yang signifikan dalam skor min kepimpinan instruksional guru besar SJKT berdasarkan jantina guru

$\mathrm{H}_{0}$ 2:Tidak terdapat perbezaan yang signifikan dalam skor min tanggapan sokongan organisasi guru SJKT berdasarkan jantina guru

$\mathrm{H}_{0} 3$ :Tidak terdapat perbezaan yang signifikan dalam skor min kepimpinan instruksional guru besar SJKT berdasarkan lokasi sekolah

$\mathrm{H}_{0} 4$ :Tidak terdapat perbezaan yang signifikan dalam skor min tanggapan sokongan organisasi guruguru SJKT berdasarkan lokasi sekolah

$\mathrm{H}_{0} 5$ :Tidak terdapat perbezaan yang signifikan dalam skor min kepimpinan instruksional guru besar SJKT berdasarkan umur guru

$\mathrm{H}_{0} 6$ :Tidak terdapat hubungan antara kepimpinan instruksional guru besar dengan tanggapan sokongan organisasi guru SJKT

\section{Sorotan Literatur}

\section{Kepimpinan Instruksional}

Menurut Harris et al. (2018), kepimpinan instruksional dikaji di seluruh dunia dan semakin popular dalam dunia pendidikan. Hallinger dan Murphy (1985) mendefinisikan kepimpinan instruksional sebagai perlakuan ketua sekolah atau individu yang bertanggungjawab dalam mengurus, memantau, menilai serta memimpin aktiviti pengajaran dan pembelajaran (PdPc) di peringkat sekolah. Hal ini menyebabkan pemimpin instruksional dilihat sebagai sumber mutlak yang bertindak secara "insitu" dalam menerajui guru menerusi kepakaran instruksionalnya. Oleh itu, kerajaan telah memperuntukkan kuasa kepada pemimpin instruksional bagi memantau, menilai dan membimbing guru-guru sebagai langkah untuk memantapkan PdPc di peringkat sekolah (Surat Ikhtisas, 3/1987). 
Pengiktirafan yang diterima dari kerajaan membantu pemimpin instruksional dalam membentuk dan membimbing perlakuan guru selaras dengan matlamat sekolah (Bada et al., 2020). Tambahan lagi, pemimpin instruksional turut dilihat sebagai individu yang bertanggungjawab dalam mewujudkan persekitaran kerja yang kodusif (Ithnin \& Abdullah, 2018) serta berusaha menjaga kebajikan guru di sekolah (Syed Imam \& Ibrahim, 2010). Usaha pemimpin instruksional dalam memenuhi kehendak warga sekolah dapat mewujudkan jalinan hubungan baik antara pemimpin dan guru. Disamping mengoptimakan motivasi kerja guru (Sanchez et al., 2020), hubungan baik antara guru dengan pemimpin instruksional ini juga dipercayai dapat mengurangkan kadar perpindahan guru (Qadach \& Schechter, 2020), meningkatkan komitmen dan kepuasan kerja (Al-Mahdy et al., 2018; Abd Wahab \& Abdullah, 2018) serta meningkatkan kualiti pengajaran guru (Shaked, 2019).

\section{Tanggapan Sokongan Organisasi}

Guru yang berkualiti adalah asas kepada kejayaan sesebuah sekolah. Guru-guru yang mahir, komited dan sanggup bekerjasama dalam mencapai matlamat sekolah merupakan idaman pihak pengurusan. Para guru diharap dapat mengasah kemahiran dan mengemas kini teknik PdPc terkini yang diperlukan untuk mengajar para pelajar dengan efektif. Namun demikian, Liu (2015) berpendapat bahawa guruguru hanya akan melaksanakan tugas dengan terbaik apabila mendapat sokongan pihak pengurusan sekolah. Pendapat ini turut disokong kajian lepas yang dilakukan oleh Duan et al. (2020) serta Rhoades dan Eisenberger (2002). Kajian-kajian ini menyatakan bahawa persekitaran yang menyokong mampu meningkatkan motivasi dalaman serta meningkatkan kualiti dan kepuasan kerja. Hal ini kerana sokongan organisasi adalah konstruk di peringkat individu (Yang et al., 2020) serta berfungsi secara timbal balik berasaskan teori pertukaran sosial (Blau, 1964). Segala inisiatif yang dilakukan oleh pihak pemimpin bagi meningkatkan kebajikan pekerja seperti mewujudkan persekitaran kerja yang baik selain daripada peningkatan gaji dan pangkat (Rhoades et al., 2001) akan dibalas dengan kepatuhan dan komitmen kerja yang tinggi daripada mereka.

Kajian-kajian lepas membuktikan bahawa tanggapan sokongan organisasi telah memberikan pelbagai impak yang positif. Sebagai contohnya, kajian yang dilakukan oleh Gündüz (2017) menunjukkan bahawa sokongan organisasi mampu meningkatkan persepsi positif, prestasi, dan komitmen kerja dalam kalangan guru. Selain itu, kajian yang dilakukan oleh Yang et al. (2020) melaporkan kewujudan budaya perkongsian ilmu di antara guru turut meningkatkan kepercayaan mereka terhadap sokongan organisasi sekolah. Bukan itu sahaja, kajian-kajian yang dilakukan oleh Duan et al. (2020), Kurtessis et al. (2017) serta Van et al. (2015) juga menunjukkan pelbagai impak positif hasil daripada sokongan organisasi. Antara impak positif ini adalah peningkatan kreativiti kerja, memberi makna terhadap hidup, dan perlakuan positif kewarganegaraan organisasi. Sokongan yang diterima daripada pihak organisasi juga boleh meningkatkan kepercayaan dan meningkatkan kepatuhan guru kepada peraturan sekolah tanpa sebarang bantahan. Sekolah yang berjaya menawan hati guru mampu meningkatkan prestasi pendidikan secara mendadak. Hal ini adalah kerana layanan pihak pengurusan mampu mengembangkan potensi guru ke tahap tertinggi. Oleh itu, sebarang langkah yang diambil bagi menjaga kebajikan warga sekolah melalui sokongan organisasi amatlah digalakkan.

\section{Metod Kajian}

\section{Reka Bentuk Kajian}

Kajian ini menggunakan reka bentuk tinjauan jenis kuantitatif yang menggunakan borang Google (Google forms) sebagai medium untuk mengumpul data.

\section{Populasi dan Sampel Kajian}

Populasi kajian ini terdiri daripada guru-guru terlatih SJKT di negeri Pulau Pinang. Sampel kajian seramai 210 orang guru telah dipilih secara rawak dari 19 buah SJKT menggunakan teknik persampelan berstrata berdasarkan jadual pemilihan saiz sampel Krejcie dan Morgan (1970). 


\section{Instrumen Kajian}

Instrumen kajian ini terdiri daripada tiga bahagian. Bahagian A sebagai bahagian pertama adalah untuk mengumpul maklumat latar belakang demografi responden manakala Bahagian B dan Bahagian C sebagai bahagian kedua dan ketiga pula masing-masing bagi menjawab soalan-soalan kajian. Instrumen pertama yang digunakan pada Bahagian A ialah Principal Instructional Management Rating Scale (PIMRS) versi ringkas (teachers short form) dan mengandungi 3 dimensi dan 22 item. Instrumen ini dibina oleh Hallinger et al. (2015). Instrumen kedua pada Bahagian B pula ialah tanggapan sokongan organisasi yang diuji menggunakan Survey of Perceived Organizational Support (SPOS). Instrumen ini mengandungi 8 item dan dibina oleh Eisenberger et al. (1986). Kesemua item dalam instrumeninstrumen ini diukur menerusi skala Likert lima mata, dari "Sangat tidak setuju = 1" hingga "Sangat setuju $=5 "$.

\section{Analisis Data}

Data kajian dikumpulkan dan dianalisis menggunakan perisian Statistical Package for Social Sciences (SPSS) versi 26. Analisis data dimulakan dengan menguji kebolehpercayaan instrumen kajian. Dapatan ujian menunjukkan nilai pekali Cronbach Alpha berada di antara nilai 0.86 hingga 0.95. Data kajian diteruskan dengan statistik deskriptif dan inferensi. Statistik deskriptif digunakan bagi memerihalkan data-data kekerapan, peratusan dan skor min. Dalam kajian ini, skor min digunakan bagi menentukan tahap amalan kepimpinan instruksional guru besar dan tanggapan sokongan organisasi guru-guru SJKT. Tahap skor min ditentukan mengikut saranan daripada Konting (2004). Mengikut beliau, nilai skor min boleh dibahagikan kepada tiga tahap iaitu tahap rendah (1.00 hingga 2.33), tahap sederhana (2.34 hingga 3.67) dan tahap tinggi (3.68 hingga 5.00). Statistik inferensi pula digunakan untuk menjawab enam hipotesis kajian melalui ujian parametrik, Ujian-t sampel bebas, ANOVA sehala dan Ujian Korelasi Pearson.

\section{Kerangka Kajian}

Kerangka kajian seperti yang diilustrasikan oleh Rajah 1 memaparkan hubungan antara kepimpinan instruksional guru besar dengan tanggapan sokongan organisasi guru-guru di SJKT. Kepimpinan instruksional diklasifikasikan sebagai variabel bebas manakala tanggapan sokongan organisasi pula sebagai variabel bersandar. Kajian ini dipercayai mampu memperincikan hubungan antara kepimpinan instruksional guru besar dengan tanggapan sokongan organisasi guru-guru SJKT secara sistematik khususnya di peringkat negeri Pulau Pinang.

Rajah 1: Kerangka Kajian

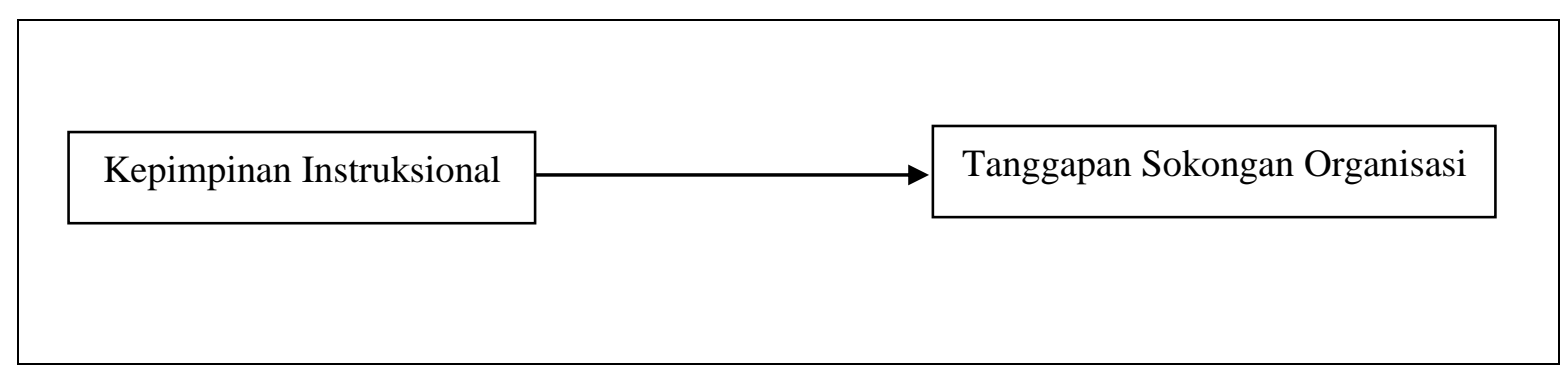

\section{Hasil Kajian}

Jadual 1 menunjukkan maklumat tentang 210 orang guru yang telah mengambil bahagian dalam kajian ini. Daripada 210 orang guru, seramai $161(77 \%)$ adalah guru perempuan manakala bakinya seramai 49 orang (23\%) adalah guru lelaki. Dari segi bangsa pula, responden berbangsa India menerajui penyertaan di dalam kajian ini dengan bilangan seramai 170 orang $(81 \%)$, diikuti responden berbangsa Melayu seramai 33 orang (16\%) dan lain-lain bangsa seramai 7 orang (3\%). Umur responden kajian pula boleh dikategorikan kepada empat kumpulan. Kumpulan pertama adalah responden berumur 20 
DOI: https://doi.org/10.47405/mjssh.v6i4.740

hingga 30 tahun seramai 31 orang (15\%) manakala kumpulan kedua adalah responden berumur 31 hingga 40 tahun seramai 88 orang (42\%). Kumpulan ketiga dan keempat terdiri daripada responden berumur 41 hingga 50 tahun seramai 61 orang (29\%) dan berumur 51 hingga 60 tahun seramai 30 orang (14\%). Pengalaman mengajar responden juga turut dibahagikan kepada empat kumpulan iaitu 1 hingga 10 tahun seramai 60 orang (28.5\%), 11 hingga 20 tahun seramai 104 orang (49.5\%), 21 hingga 30 tahun seramai 35 orang (16.7) dan 31 hingga 40 tahun seramai 11 orang (5.3\%). Dari segi lokasi, 155 orang responden $(73.8 \%)$ bertugas di sekolah di bandar manakala 55 orang responden $(26.2 \%)$ bertugas di sekolah luar bandar.

Jadual 1: Maklumat Guru

\begin{tabular}{llcc}
\hline & Guru & Kekerapan & Peratus \% \\
\hline \multirow{3}{*}{ Jantina } & Lelaki & 49 & 23.3 \\
& Perempuan & 161 & 76.6 \\
& Jumlah & $\mathbf{2 1 0}$ & $\mathbf{1 0 0}$ \\
Bangsa & India & 170 & 81.0 \\
& Melayu & 33 & 15.7 \\
& Lain-lain & 7 & 3.3 \\
& Jumlah & $\mathbf{2 1 0}$ & $\mathbf{1 0 0}$ \\
Umur & 20-30 Tahun & 31 & 14.7 \\
& 31-40 Tahun & 88 & 42.0 \\
& 41-50 Tahun & 61 & 29.0 \\
& 51-60 Tahun & 30 & 14.3 \\
Pengalaman & $\mathbf{2 1 0}$ & $\mathbf{1 0 0}$ \\
& Jumlah & 60 & 28.5 \\
& 01-10 Tahun & 104 & 49.5 \\
& 11-20 Tahun & 35 & 16.7 \\
Lokasi & 21-30 Tahun & 11 & 5.3 \\
& 31-40 Tahun & $\mathbf{2 1 0}$ & $\mathbf{1 0 0}$ \\
& Jumlah & 155 & 73.8 \\
& Bandar & 55 & 26.2 \\
& Luar Bandar & $\mathbf{2 1 0}$ & $\mathbf{1 0 0}$ \\
\hline
\end{tabular}

\section{Tahap Kepimpinan Instruksional Guru Besar SJKT}

Jadual 2 menunjukkan tahap kepimpinan instruksional guru besar SJKT. Dimensi kepimpinan instruksional terdiri daripada mendefinisikan misi sekolah dengan skor min sebanyak 4.15, mengurus program instruksional dengan skor min sebanyak 4.12 dan membentuk iklim sekolah sebagai dimensi terakhir pula mempunyai skor min sebanyak 4.07. Ketiga-tiga dimensi kepimpinan instruksional ini dikategorikan sebagai tahap tinggi. Secara keseluruhan pula, nilai skor min kepimpinan instruksional guru besar SJKT adalah sebanyak 4.10. Dengan bacaan nilai ini, ianya boleh disimpulkan bahawa nilai skor min berdasarkan dimensi menunjukkan tahap amalan kepimpinan instruksional guru besar SJKT berada pada tahap tinggi.

Jadual 2: Tahap Kepimpinan Instruksional Guru Besar SJKT

\begin{tabular}{lcc}
\hline Dimensi & Min & Tahap \\
\hline Kepimpinan Instruksional & $\mathbf{4 . 1 0}$ & Tinggi \\
Mendefinisi Misi Sekolah & 4.15 & Tinggi \\
Mengurus Program Instruksional & 4.12 & Tinggi \\
Membentuk Iklim Sekolah yang Positif & 4.07 & Tinggi \\
\hline
\end{tabular}




\section{Tahap Tanggapan Sokongan Organisasi}

Jadual 3 menunjukkan tahap tanggapan sokongan organisasi guru-guru SJKT. Tahap tanggapan sokongan organisasi guru-guru SJKT menunjukkan skor min bersamaan dengan 4.24. Nilai skor min ini menjelaskan bahawa tahap sokongan organisasi di SJKT berada pada tahap tinggi.

Jadual 3: Tanggapan Sokongan Organisasi

\begin{tabular}{lll}
\hline Variabel & Min & Tahap \\
\hline Tanggapan Sokongan Organisasi & 4.24 & Tinggi \\
\hline
\end{tabular}

\section{Hipotesis Ho1: Tidak terdapat perbezaan dalam skor min kepimpinan instruksional guru besar SJKT berdasarkan jantina guru}

Hipotesis $\mathrm{H}_{0} 1$, diuji menggunakan ujian-t sampel bebas. Ujian ini digunakan untuk membandingkan skor min (compare means) variabel bebas di antara dua kumpulan. Seperti yang ditunjukkan pada Jadual 4, variabel bebas yang digunakan dalam ujian ini ialah jantina guru iaitu, lelaki dan perempuan. Aras signifikan nilai $p$ telah ditetapkan pada nilai $p<0.05$. Nilai ujian persamaan Levene dirujuk bagi menentukan ketepatan data.

Dapatan kajian ini menunjukkan bahawa skor min antara guru lelaki dan perempuan terhadap tahap kepimpinan instruksional guru besar SJKT mempunyai perbezaan sebanyak 0.06. Skor min guru lelaki $(\mathrm{M}=4.06, \mathrm{SP}=.71, \mathrm{~N}=49)$ adalah lebih rendah berbanding skor min guru perempuan $(\mathrm{M}=4.12, \mathrm{SP}=.46$, $\mathrm{N}=161$ ). Berdasarkan skor min ini, penerimaan aspek-aspek kepimpinan instruksional guru besar oleh guru-guru perempuan adalah lebih tinggi berbanding penerimaan aspek-aspek kepimpinan instruksional guru besar oleh guru lelaki. Hal ini turut dibuktikan melalui dapatan ujian-t $(\mathrm{t}=-.671$, $\mathrm{df}=208, \mathrm{p}>0.05)$. Oleh itu, Hipotesis $\mathrm{H}_{0} 1$ ditolak.

Jadual 4: Analisis Ujian-t Kepimpinan Instruksional Berdasarkan Jantina Guru

\begin{tabular}{lllllllc}
\hline \multirow{2}{*}{ K1 } & $\begin{array}{c}\text { Variabel } \\
\text { Bebas }\end{array}$ & M & SP & F & Nilai-t & df & $\begin{array}{c}\text { Sig } \\
\text { (2-Hujung) }\end{array}$ \\
\cline { 2 - 8 } & $\begin{array}{l}\text { Lelaki } \\
\text { Perempuan }\end{array}$ & 4.06 & .71 & 13.47 & -.671 & 208 & .503 \\
\hline
\end{tabular}

Signifikan pada tahap $\mathrm{p}<0.05$ (2-Hujung)

KI: Kepimpinan Instruksional

\section{Hipotesis Ho2: Tidak terdapat perbezaan dalam skor min sokongan organisasi guru- guru SJKT berdasarkan jantina}

Bagi menentukan perbezaan skor min sokongan organisasi guru-guru SJKT berdasarkan jantina, kajian ini menggunakan ujian-t sampel bebas. Jantina peserta iaitu, lelaki dan perempuan digunakan sebagai variabel bebas dalam ujian ini. Aras signifikan nilai $p$ ditetapkan pada nilai $p<0.05$. Ujian persamaan Levene turut dibuat bagi menentukan ketepatan data. Jadual 5, memaparkan dapatan kajian yang membandingkan nilai skor min antara guru lelaki dan perempuan.

Hasil kajian menunjukkan bahawa terdapat perbezaan dalam skor min antara guru lelaki dan perempuan terhadap tahap persepsi sokongan organisasi guru di SJKT sebanyak 0.05. Skor min guru lelaki $(\mathrm{M}=3.84, \mathrm{SP}=.61, \mathrm{~N}=49)$ adalah lebih rendah berbanding skor min guru perempuan $(\mathrm{M}=3.89$, $\mathrm{SP}=.70, \mathrm{~N}=161)$. Dapatan ujian-t pula, turut menunjukkan bahawa tidak signifikan $(\mathrm{t}=-.431, \mathrm{df}=208$, $\mathrm{p}>0.05)$. Justeru, dapatan ini menunjukkan bahawa terdapat perbezaan yang signifikan dalam sokongan organisasi antara guru lelaki dan perempuan SJKT. Oleh itu, Hipotesis $\mathrm{H}_{0} 2$ ditolak. 
DOI: https://doi.org/10.47405/mjssh.v6i4.740

Jadual 5: Analisis Ujian-t Sokongan Organisasi Berdasarkan Jantina Guru

\begin{tabular}{cllllllc}
\hline \multirow{2}{*}{ SO } & \multicolumn{1}{c}{$\begin{array}{c}\text { Variabel } \\
\text { Bebas }\end{array}$} & M & SP & F & Nilai-t & df & $\begin{array}{c}\text { Sig } \\
\text { (2-Hujung) }\end{array}$ \\
\cline { 2 - 8 } & Lelaki & 3.84 & .61 & .264 & -.431 & 208 & .667 \\
& Perempuan & 3.89 & .70 & & & & \\
\hline
\end{tabular}

Signifikan pada tahap $\mathrm{p}<0.05$ (2-Hujung)

SO: Sokongan Organisasi

\section{Hipotesis Ho3: Tidak terdapat perbezaan dalam skor min kepimpinan instruksional guru besar SJKT berdasarkan lokasi sekolah}

Hipotesis ini diuji menggunakan ujian-t sampel bebas. Ujian ini digunakan untuk membandingkan skor min (compare means) variabel bebas antara dua kumpulan lokasi iaitu responden yang bertugas di sekolah bandar dan responden yang bertugas di sekolah luar bandar. Aras signifikan nilai p ditetapkan pada nilai $\mathrm{p}<0.05$. Nilai ujian persamaan Levene dirujuk bagi menentukan ketepatan data. Jadual 6 memaparkan dapatan kajian yang membandingkan nilai skor min lokasi antara dua kumpulan.

Dapatan kajian menunjukkan bahawa terdapat perbezaan dalam skor min sebanyak 0.11 antara guruguru yang bertugas di sekolah bandar dan luar bandar terhadap persepsi kepimpinan instruksional guru besar SJKT. Skor min responden yang bertugas di sekolah bandar $(\mathrm{M}=4.13, \mathrm{SP}=.51, \mathrm{~N}=155)$ adalah lebih tinggi berbanding skor min responden yang bertugas di sekolah luar bandar $(\mathrm{M}=4.02, \mathrm{SP}=.56$, $\mathrm{N}=55$ ). Dengan ini guru-guru yang bertugas di sekolah bandar mengakui bahawa mereka menerima aspek-aspek kepimpinan instruksional guru besar dengan lebih terbuka. Dapatan ujian-t menunjukkan signifikan $(\mathrm{t}=1.35, \mathrm{df}=208, \mathrm{p}>0.05)$. Secara kesimpulannya, terdapat perbezaan dalam persepsi terhadap kepimpinan instruksional guru besar SJKT antara guru yang bertugas di sekolah bandar dan luar bandar. Oleh itu, Hipotesis $\mathrm{H}_{0} 3$ ditolak.

Jadual 6: Analisis Ujian-t Kepimpinan Instruksional Berdasarkan Lokasi Sekolah

\begin{tabular}{lllllllc}
\hline \multirow{2}{*}{ KI } & \multicolumn{1}{c}{$\begin{array}{c}\text { Variabel } \\
\text { Bebas }\end{array}$} & M & SP & F & Nilai-t & df & Sig(2-Hujung) \\
\cline { 2 - 7 } & Bandar & 4.13 & .51 & .028 & 1.35 & 208 & .178 \\
& Luar Bandar & 4.02 & .56 & & & & \\
\hline
\end{tabular}

Signifikan pada tahap $\mathrm{p}<0.05$ (2-Hujung)

KI: Kepimpinan Instruksional

\section{Hipotesis Ho4: Tidak terdapat perbezaan dalam skor min tanggapan sokongan organisasi guru-guru SJKT berdasarkan lokasi sekolah}

Bagi menentukan perbezaan skor min tanggapan sokongan organisasi guru-guru SJKT berdasarkan lokasi, ujian-t sampel bebas telah digunakan. Jadual 7, memaparkan lokasi sekolah iaitu, sekolah bandar dan luar bandar yang digunakan sebagai variabel bebas dalam ujian ini. Aras signifikan nilai $p$ ditetapkan pada nilai $\mathrm{p}<0.05$. Ujian persamaan Levene turut dibuat bagi menentukan ketepatan data. Dapatan kajian menunjukkan bahawa terdapat perbezaan dalam skor min sebanyak -0.11 antara guru yang bertugas di sekolah bandar dan luar bandar.

Skor min guru yang bertugas di sekolah bandar $(\mathrm{M}=3.85, \mathrm{SP}=.69, \mathrm{~N}=155)$ adalah lebih rendah berbanding skor min guru yang bertugas di sekolah luar bandar $(\mathrm{M}=3.96, \mathrm{SP}=.66, \mathrm{~N}=55)$. Guru-guru SJKT yang bertugas di sekolah bandar mengakui bahawa mereka menerima kurang sokongan organisasi. Dapatan ujian-t juga menunjukkan nilai signifikan $(t=-1.00, d f=208, p>0.05)$. Justeru, dapatan ini menunjukkan terdapat perbezaan yang signifikan dalam sokongan organisasi antara guruguru SJKT yang bertugas di sekolah bandar dengan luar bandar. Oleh itu, Hipotesis $\mathrm{H}_{0} 4$ ditolak. 
DOI: https://doi.org/10.47405/mjssh.v6i4.740

Jadual 7: Analisis Ujian-t Sokongan Organisasi Berdasarkan Lokasi Sekolah

\begin{tabular}{|c|c|c|c|c|c|c|c|}
\hline SO & $\begin{array}{c}\text { Variabel } \\
\text { Bebas }\end{array}$ & $\mathbf{M}$ & SP & F & Nilai-t & df & $\begin{array}{c}\text { Sig } \\
\text { (2-Hujung }\end{array}$ \\
\hline & Bandar & 3.85 & .69 & .111 & -1.00 & 208 & .317 \\
\hline & Luar Bandar & 3.96 & .66 & & & & \\
\hline
\end{tabular}

Signifikan pada tahap $\mathrm{p}<0.05$ (2-Hujung)

SO: Sokongan Organisasi

\section{Hipotesis Ho5: Tidak terdapat perbezaan yang signifikan dalam tahap kepimpinan instruksional guru besar SJKT berdasarkan umur guru}

Ujian ANOVA sehala digunakan untuk melihat perbezaan dalam penerimaan aspek-aspek kepimpinan instruksional guru besar dalam kalangan guru-guru SJKT berdasarkan umur mereka. Dalam ujian ini, umur guru-guru SJKT ditentukan sebagai variabel bebas. Manakala, kepimpinan instruksional guru besar pula sebagai variabel bersandar. Dapatan analisis deskriptif menunjukkan bahawa guru berumur antara 20 hingga 30 tahun memperoleh nilai min sebanyak 4.44. Seterusnya, guru-guru berumur antara 31 hingga 40 tahun, 41 hingga 50 tahun dan 51 hingga 60 tahun pula menunjukkan skor min sebanyak 4.04, 4.06, dan 4.01. Secara kesimpulannya, guru-guru berumur 20 hingga 30 tahun menunjukkan skor min tertinggi. Sebaliknya, guru-guru berumur antara 51 hingga 60 menunjukkan skor min terendah.

Jadual 8: Skor Min Kepimpinan Instruksional Guru Besar Berdasarkan Umur Guru

\begin{tabular}{lcc}
\hline Umur Peserta & n & Min \\
\hline 20 tahun hingga 30 tahun & 31 & 4.44 \\
31 tahun hingga 40 tahun & 88 & 4.04 \\
41 tahun hingga 50 tahun & 61 & 4.06 \\
51 tahun hingga 60 tahun & 30 & 4.01 \\
\hline
\end{tabular}

Seterusnya, keputusan ujian ANOVA sehala yang dipaparkan dalam Jadual 9 mendedahkan bahawa tidak wujud perbezaan yang signifikan dalam nilai skor min amalan kepimpinan instruksional guru besar berdasarkan umur guru-guru SJKT $(\mathrm{F}=5.23 ; \mathrm{p}<.05)$. Oleh itu, hipotesis $\mathrm{H}_{0} 5$ diterima.

Jadual 9: Keputusan ANOVA Sehala Bagi Perbezaan Amalan Kepimpinan Instruksional Berdasarkan Umur Guru

\begin{tabular}{lccccc}
\hline \multicolumn{1}{c}{ Sumber } & $\begin{array}{c}\text { Jumlah Kuasa } \\
\text { Dua }\end{array}$ & DF & $\begin{array}{c}\text { Min Kuasa } \\
\text { Dua }\end{array}$ & F & Sig \\
\hline Antara Kumpulan & 4.18 & 3 & 1.39 & 5.23 & .002 \\
Dalam Kumpulan & 54.81 & 206 & .26 & & \\
Jumlah & 59.00 & 209 & & & \\
\hline
\end{tabular}

Signifikan pada tahap $\mathrm{p}<0.05$ (2-Hujung)

\section{Hipotesis Ho6: Tidak terdapat hubungan antara kepimpinan instruksional dengan tanggapan sokongan organisasi}

Ujian analisis Korelasi Pearson dilakukan bagi menentukan hubungan antara variabel bebas iaitu kepimpinan instruksional guru besar dengan variabel bersandar tanggapan sokongan organisasi. Dapatan kajian ini dengan nilai $\mathrm{r}=0.089$ dan $\operatorname{sig}=.200(\mathrm{P}<.05)$ menunjukkan bahawa tidak terdapat hubungan antara tanggapan sokongan organisasi dengan kepimpinan instruksional guru besar SJKT. Seterusnya, hubungan antara kedua-dua variabel ini didapati sangat lemah. Oleh itu, kajian ini menerima Hipotesis $\mathrm{H}_{0} 6$. 
DOI: https://doi.org/10.47405/mjssh.v6i4.740

Jadual 10: Analisis Korelasi Pearson Kepimpinan Instruksional dengan Sokongan Organisasi

\begin{tabular}{llc}
\hline Variabel & & Tanggapan Sokongan Organisasi \\
\hline \multirow{3}{*}{ Kepimpinan Instruksional } & Korelasi Pearson (r) & 0.089 \\
& Sig (2-hujung) & 0.200 \\
& $\mathrm{~N}$ & 210 \\
\hline
\end{tabular}

Signifikan pada tahap $\mathrm{p}<0.05$ (2-Hujung)

\section{Perbincangan Kajian}

\section{Tahap Amalan Kepimpinan Instruksional}

Kajian ini menunjukkan bahawa tahap amalan kepimpinan instruksional guru besar SJKT negeri Pulau Pinang adalah tinggi. Dapatan ini adalah selaras dengan kajian Ismail et al. (2018). Seterusnya, dapatan ini turut menjelaskan bahawa guru besar SJKT memberi keutamaan kepada aspek-aspek mendefinisi misi sekolah sejajar dengan tugas dan tanggungjawab pemimpin instruksional. Tambahan lagi, guru besar selaku ketua sekolah didapati mencari alternatif terbaik untuk memperbaiki kelemahan sekolah dengan memperkasa matlamat yang dipersetujui secara bersama (Ismail et al., 2018), mengurus program instruksional (Adams et al., 2018) sejajar dengan dasar kerajaan yang menekankan kemenjadian pelajar (Awangku Amin \& Mohd Hamzah, 2021). Namun demikian, dimensi membentuk iklim sekolah yang positif memperoleh skor min yang agak rendah berbanding dimensi-dimensi kepimpinan instruksional lain. Dapatan ini disokong oleh Ithnin dan Abdullah (2018). Hasil kajian ini boleh dianggap sebagai peringatan mesra kepada guru-guru besar SJKT supaya memberi perhatian serius terhadap persekitaran kerja (Ramakrishnan \& Abd Hamid, 2020).

Seterusnya, persepsi terhadap amalan kepimpinan instruksional guru besar SJKT didapati berbeza antara guru-guru lelaki dan perempuan. Hal ini mungkin kerana secara nalurinya persepsi antara guru lelaki dan wanita terhadap sesuatu perkara adalah berbeza (Sanchez et al., 2020). Tambahan lagi, guru wanita terkenal sebagai pengikut (Gutermann et al., 2017). Hal ini mungkin menyebabkan guru-guru wanita mudah menerima arahan pemimpin instruksional di sekolah. Selain itu, Hallinger et al. (2016) juga berpendapat bahawa guru-guru besar wanita lebih komited berbanding guru-guru besar lelaki. Ciri-ciri ini mungkin mendorong guru besar wanita patuh akan permintaan kerajaan yang menggalakan pemimpin sekolah menjadikan kemimpinan instruksional sebagai model asas dalam mentadbir sekolah. Keadaan ini mungkin disebabkan guru besar wanita dan guru-guru wanita mengamal serta menyokong kepimpinan instruksional di sekolah mereka.

Dari segi lokasi dengan amalan kepimpinan pula, kajian Saat dan Zain (2016) menerangkan bahawa faktor lokasi tidak mempengaruhi tahap amalan kepimpinan. Manakala, Sindhvad et al. (2020) mendapati bahawa faktor lokasi mungkin mempengaruhi tahap amalan kepimpinan. Walaupun keduadua kajian menujukkan dapatan yang bertentangan, hasil kajian ini mendedahkan bahawa wujud perbezaan yang signifikan dalam amalan kepimpinan instruksional guru besar antara SJKT bandar dengan luar bandar. Tahap amalan kepimpinan instruksional guru besar SJKT bandar didapati lebih tinggi berbanding luar bandar. Hal ini mungkin kerana sekolah bandar besar dari segi saiz dan bilangan guru berbanding sekolah luar bandar. Tambahan lagi, ibu bapa murid-murid dibandar berkemungkinan lebih peka tentang kepentingan prestasi pendidikan. Faktor-faktor kesedaran seperti ini mungkin telah menggalakkan guru besar SJKT berlokasi bandar untuk lebih fokus terhadap dimensi-dimensi kepimpinan instruksional.

Seterusnya, tidak terdapat perbezaan yang signifikan dalam tahap kepimpinan instruksional guru besar SJKT berdasarkan umur guru. Ini bermakna guru-guru SJKT menerima aspek-aspek kepimpinan instruksional secara sama rata tanpa mempengaruhi peringkat umur. Hal ini mendedahkan bahawa guru-guru besar SJKT mengamalkan kepimpinan instruksional tanpa bersandarkan faktor umur guru. 


\section{Tahap Tanggapan Sokongan Organisasi}

Kajian ini menjelaskan bahawa guru-guru SJKT negeri Pulau Pinang menerima sokongan organisasi yang tinggi di peringkat sekolah. Dapatan ini merupakan tanda positif dalam membina organisasi yang sihat kerana guru-guru yang menerima sokongan organisasi didapati aktif dan komited dalam tugas. Dapatan kajian ini juga dapat disimpulkan bahawa guru-guru SJKT negeri Pulau Pinang percaya akan organisasi pendidikan yang mereka berkhidmat. Namun demikian, kajian-kajian yang dilakukan oleh Ambikapathy et al. (2020), Chong et al. (2019), dan Adams et al. (2018) menunjukkan dapatan yang agak berbeza kerana responden kajian mereka mendakwa menerima sokongan yang agak rendah di peringkat sekolah. Dapatan ini berbeza mungkin disebabkan oleh persepsi peribadi guru terhadap persekitaran sekolah, budaya kerja dan gaya kepimpinan guru besar berdasarkan konteks kajian.

Seterusnya, guru-guru SJKT luar bandar didapati menerima sokongan organisasi yang lebih tinggi berbanding guru-guru SJKT bandar. Hal ini mungkin kerana SJKT luar bandar adalah kecil dari segi saiz, bilangan guru serta tidak menerima sumber kewangan yang banyak. Faktor-faktor ini menyebabkan guru besar lebih mudah berganding bahu bersama guru dalam menjalankan operasi sekolah. Situasi sebegini menyebabkan sokongan organisasi berperanan sebagai medium pengikat antara pihak pengurusan dengan guru.

Dapatan kajian turut mendedahkan bahawa guru-guru SJKT menerima sokongan organisasi tanpa perbezaan dalam peringkat umur. Hal ini kerana sokongan organisasi mendasari konsep pertukaran sosial atau menyokong antara satu sama lain. Ini bermakna, sokongan yang diberikan oleh pihak pengurusan SJKT tidak berat sebelah kepada mana-mana guru. Tambahan lagi, langkah ini mungkin dijadikan sebagai strategi untuk memotivasikan guru-guru bagi menjalankan tugas dan tanggungjawab dengan efektif serta patuh kepada arahan pihak pengurusan.

\section{Hubungan antara Amalan Kepimpinan Instruksional dengan Tanggapan Sokongan Organisasi}

Ujian Korelasi Pearson menunjukkan bahawa tidak terdapat hubungan antara amalan kepimpinan instruksional guru besar dengan tanggapan sokongan organisasi guru SJKT. Dapatan ini menjelaskan bahawa konsep sokongan organisasi adalah luas serta amalan kepimpinan bukan satu-satunya aspek yang boleh dikaitkan dengan tahap sokongan organisasi. Oleh itu, tanggapan sokongan organisasi guruguru SJKT negeri Pulau Pinang mungkin dipengaruhi oleh faktor-faktor lain seperti kepercayaan terhadap organisasi, peluang meningkatkan ilmu dan perkembangan diri (Abd. Ghani \& Tengku Raja Hussin, 2009), kepuasan kerja (Rosli et al., 2015), latihan (Giorgi et al., 2016), psikologi kapital (Mohan \& Sophia, 2019) dan perkongsian pengetahuan (Yang et al., 2020).

\section{Kesimpulan}

Kepimpinan instruksional semakin terkenal dan sering dikaitkan dengan aktiviti pengajaran dan pembelajaran sekolah. Malah, prestasi pendidikan sesebuah sekolah turut berkait rapat dengan kebolehan pemimpin instruksional. Oleh itu, pemimpin sekolah diharapkan dapat menguasai kemahiran instruksional terkini sejajar dengan perkembangan pendidikan negara. Hal ini adalah kerana banyak kajian terdahulu membuktikan bahawa pemimpin instruksional mampu melahirkan persekitaran kerja yang kondusif, membimbing guru, serta memperkasakan aktiviti pengajaran dan pembelajaran dalam mencapai matlamat sekolah. Seterusnya, tanggapan sokongan organisasi yang tinggi pula mampu memberikan keyakinan kepada guru tentang penjagaan kebajikan dan menggalakkan mereka untuk melaksanakan tanggungjawab dengan bersungguh-sungguh. Kesimpulannya, kedua-dua variabel ini (kepimpinan instruksional dan tanggapan sokongan organisasi) mempunyai peranan dan pengaruh terhadap SJKT di negeri Pulau Pinang. Namun demikian, pemimpin instruksional tidak semestinya menjadi faktor tunggal dalam menentukan tanggapan sokongan organisasi. Walaupun pemimpin instruksional merupakan individu yang berkuasa dan mampu mempengaruhi keputusan di peringkat sekolah, namun faktor-faktor lain masih berpengaruh dalam menentukan tahap tanggapan sokongan organisasi guru-guru SJKT. Antara faktor-faktor lain seperti 
yang dinyatakan di atas adalah kepercayaan terhadap organisasi, peluang meningkatkan ilmu dan perkembangan diri, kepuasan kerja, latihan, serta psikologi kapital dan perkongsian pengetahuan. Kajian masa hadapan boleh mengambil meneroka pengaruh faktor-faktor ini dengan kepimpinan instruksional dalam kajian mereka.

\section{Rujukan}

Abd. Ghani, N. A., \& Raja Hussin, T. A. B. S. (2009). Antecedents of perceived organizational support. Canadian Social Science, 5(6), 121-130.

Abd Wahab, N., \& Abdullah, M. Y. (2018). Hubungan gaya kepimpinan dan pengurusan kerja guru besar dengan kepuasan kerja guru sekolah agama kerajaan Johor. Jurnal Ilmi, 8, 136-150.

Abdulrasheed, O., \& Bello, A. S. (2015). Challenges to secondary school principals' leadership in northern region of Nigeria. British Journal of Education, 3(3), 1-5.

Adams, D., Periasamy, R., Devadason, E., \& Awang, S. (2018). Amalan kepimpinan instruksional guru besar di sekolah vernakular Negeri Selangor dan Wilayah Persekutuan. Jurnal Pusat Penataran Ilmu \& Bahasa, 28, 109-132.

Al-Mahdy, Y. F. H., Mohamed Emam, M., \& Hallinger, P. (2018). Assessing the contribution of principal instructional leadership and collective teacher efficacy to teacher commitment in Oman. Teaching and Teacher Education, 69, 191-201. https://doi.org/10.1016/j. tate.2017.10.007

Ambikapathy, A., Halili, S. H., \& Ramasamy, M. D. (2020). Kemahiran TMK dalam kalangan guruguru Bahasa Tamil Sekolah Menengah. Mualim Journal of Social Science and Humanities, 4(3), 99-114.

Awangku Amin, D. R., \& Mohd Hamzah, M. I. (2021). Tahap amalan Kepimpinan instruksional guru besar dan hubungannya dengan tahap komitmen guru. Malaysian Journal of Social Sciences and Humanities, 6(2), 135-151.

Bada, H. A., Tengku Ariffin, T. F., \& Nordin, H. (2020). The effectiveness of teachers in Nigerian secondary schools: The role of instructional leadership of principals. International Journal of Leadership in Education, 1-28. https://doi.org/10.1080/13603124.2020.1811899

Baskaran, K., \& A. Hamid, A. H. (2020). Amalan kepimpinan instruksional pengetua di sekolah menengah di bandar Banting. International Journal of Education and Pedagogy, 2(1), 264-284.

Billy, L. J., \& Taat, M. S. (2020). Budaya sekolah: Hubungannya dengan komitmen guru. Malaysian Journal of Social Sciences and Humanities, 5(10), 207-216. https://doi.org/10.47405/mjssh. v5i10.511

Blau, P. M. (1964). Justice in social exchange. Sociological Inquiry, 34(2), 193-206. https://doi.org/ 10.1111/j.1475-682X.1964.tb00583.x

Bush, T., Abdul Hamid, S., Ng, A., \& Kaparou, M. (2018). School leadership theories and the Malaysia education blueprint: Findings from a systematic literature review. International Journal of Educational Management, 32(7), 1245-1265. https://doi.org/10.1145/3132847.3132886

Chong, C. K., A. Ghani, M. F., \& Abdullah, Z. (2019). Cabaran amalan komuniti pembelajaran dalam kalangan guru sekolah rendah berprestasi tinggi Malaysia. Jurnal Kurikulum \& Pengajaran Asia Pasifik, 7(3), 35-48.

Duan, W., Tang, X., Li, Y., Cheng, X., \& Zhang, H. (2020). Perceived organizational support and employee creativity: The mediation role of calling. Creativity Research Journal, 1-9. https://doi.org/10.1080/10400419.2020.1821563

Eisenberger, R., Fasolo, P., \& Davis-lamastro, V. (1990). Perceived organizational support and employee diligence, commitment, and innovation. Journal of Applied Psychology, 75(1), 51-59. https://doi.org/10.1037/0021-9010.75.1.51

Eisenberger, R., Huntington, R., Hutchison, S., \& Sowa, D. (1986). Perceived organizational support. Journal of Applied Psychology, 71(3), 500-507.

Giorgi, G., Dubin, D., \& Perez, J. F. (2016). Perceived organizational support for enhancing welfare at work: A Regression Tree Model. Frontiers in Psychology, 7. https://doi.org/10.3389/fp syg.2016.01770

Gündüz, Y. (2017). The effect of organizational support on organizational commitment the effect of organizational support on organizational commitment. The Anthropologist, 18(3), 1041-1057. https://doi.org/10.1080/09720073.2014.11891587 
Gutermann, D., Lehmann-willenbrock, N., Boer, D., Born, M., \& Voelpel, S. C. (2017). How leaders affect followers' work engagement and performance: Integrating leader - Member Exchange and Crossover Theory. British Journal of Management, 28, 299-314. https://doi.org/10. 1111/14678551.12214

Hallinger, P., Dongyu, L., \& Wang, W. C. (2016). Gender differences in instructional leadership: A meta-analytic review of studies using the principal instructional management rating scale. Educational Administration Quarterly, 52(4), 567-601. https://doi.org/10.1177/0013161X1663 8430

Hallinger, P., \& Moosung Lee. (2013). Exploring principal capacity to lead reform of teaching and learning quality in Thailand. International Journal of Educational Development, 33(4), 305-315. https://doi.org/10.1016/j.ijedudev.2012.03.002

Hallinger, P., \& Murphy, J. (1985). Assessing the instructional management behavior of principals. The Elementary School Journal, 86(2), 217-247. https://doi.org/10.1086/461445

Hallinger, P., \& Wang, W. C. (2015). Assessing instructional leadership with the principal instructional management rating scale. Springer International Publishing Switzerland.

Harris, A., Jones, M., Adams, D., \& Cheah, K. (2018). Instructional leadership in Malaysia: A review of the contemporary literature. School Leadership and Management, 39(1), 76-95. https://doi.org/10.1080/13632434.2018.1453794

Hassan, Z. A., Quah, C. S., \& Radin. (2017). Instructional leadership in Malaysia: Roles, practices and challenges in high performing school. In Asia Leadership roundtable 2017. Taipei. Retrieved from https://www.eduhk.hk/apclc/roundtable2017/paper/PaperDrHajiZainalAalambinHassan.pdf

Ismail, S. N., Don, Y., Husin, F., \& Khalid, R. (2018). Instructional leadership and teachers' functional competency across the 21st century learning. International Journal of Instruction, 11(3), 135-252. https://doi.org/10.12973/iji.2018.11310a

Ithnin, A., \& Abdullah, Z. (2018). Kepimpinan instruksional pengetua Seberang Perai Selatan, Pulau Pinang. Jurnal Kepimpinan Pendidikan, 5(3), 72-94.

Jekri, A., \& Han, C. G. K. (2020). Pengaruh pengalaman mengajar dalam pengetahuan, motivasi dan pelaksanaan pengajaran dan pembelajaran STEM. Jurnal Pendidikan Sains \& Matematik Malaysia, 10(2), 45-56.

Jose, S. A., \& Mohd Matore, M. E. (2021). Tinjauan literatur bersistematik: Faktor burnout dalam kalangan Guru. Malaysian Journal of Social Sciences and Humanities, 6(1), 168-186. https://doi. org/ 10.47405/mjssh.v6i1.628

Kamarudin, S., \& Taat, M. S. (2020). Pengaruh faktor-faktor tekanan kerja dalam kalangan Guru di Sekolah Menengah: Satu Analisis Persamaan Struktur (SEM-PLS). Malaysian Journal of Social Sciences and Humanities, 5(11), 104-115. https://doi.org/10.47405/mjssh.v5i 11.544

Konting, M. M. (2004). Kaedah penyelidikan pendidikan. Dewan Bahasa Dan Pustaka.

Krejcie, R. V., \& Morgan, D. W. (1970). Determining sample size for research activities. Educational and Psychological Measurement, 30, 607-610.

Kurtessis, J. N., Eisenberger, R., T., Ford, M., C. Buffardi, L., A.Stewart, K., \& Adis, C. S. (2017). Perceived Organizational Support: A meta-analytic evaluation of Organizational Support Theory. Journal of Management, 1-31. https://doi.org/10.1177/0149206315575554

Liu, P. (2015). Motivating teachers' commitment to change through transformational school leadership in Chinese urban upper secondary schools. Journal of Educational Administration, 53(6), 735-754. https://doi.org/10.1108/JEA-02-2014-0026

Mohan, A., \& Sophia, S. (2019). The influence of psychological capital on the perceived organizational support of it professionals. Antecedents of Perceived Organizational Support, 6(1), $2626-2629$.

Othman, Z. (2016). Kepimpinan instruksional guru besar di sekolah kurang murid. Universiti Malaya.

Pineda-Báez, C., Bernal-Luque, R., Sandoval-Estupiñan, L. Y., \& Quiroga, C. (2019). Challenges facing novice principals: A study in Colombian schools using a socialisation perspective. Issues in Educational Research, 29(1), 205-222.

Qadach, M., \& Schechter, C. (2020). Instructional leadership and teachers' intent to leave: The mediating role of collective teacher efficacy and shared vision. Educational Management Administration \& Leadership, 48(4), 617-634. https://doi.org/10.1177/1741143219836683 
Ramakrishnan, K., \& Abd Hamid, A. H. (2020). Kepimpinan strategik dan hubungannya dengan kualiti pengajaran guru di sekolah kluster Tamil daerah Pasir Gudang. Jurnal Dunia Pendidikan, 2(2), 57-64.

Rhoades, L., \& Eisenberger, R. (2002). Perceived organizational support: A review of the literature. Journal of Applied Psychology, 87(4), 698-714. https://doi.org/10.1037//0021-9010. 87.4.698

Rhoades, L., Eisenberger, R., \& Armeli, S. (2001). Affective commitment to the organization: The contribution of perceived organizational support. Journal of Applied Psychology, 86(5), 825-836. https://doi.org/10.1037/0021-9010.86.5.825

Rosli, R., AB Wahab, N., \& Bakar, A. (2015). Roles of organizational support in quality of work life in insurance industry. Journal of Economics, Business and Management, 3(8). https://doi.org/10. 7763/JOEBM. 2015.V3.280.

Saat, L. B., \& Zain, S. (2016). Pengaruh kepimpinan instruksional, efikasi dan tugas rutin pengetua terhadap pencapaian akademik. Malaysian Journal of Social Sciences and Humanities, 1(3), 4265.

Saleem, Z., Batool, S., \& Khattak, S. R. (2017). Relationship between leadership styles and organizational commitment: Moderating role of emotional intelligence and organizational support. Journal of Managerial Sciences, 11(1), 71-84. Retrieved from qurtuba.edu.pk

Sanchez, J. E., Paul, J. M., \& Thornton, B. W. (2020). Relationships among teachers' perceptions of principal leadership and teachers' perceptions of school climate in the high school setting. International Journal of Leadership in Education, 1-21. https://doi.org/10.1080/13603124.2019 .1708471

Seman, M. S., A. Ghani, M. F., Syed Ali, S. K., Hamid, R., \& Mat Som, M. F. (2021). Tahap keberkesanan sekolah sukan di Malaysia. Jurnal Kepimpinan Pendidikan, 8(1), 61-87.

Shaked, H. (2019). Perceptual inhibitors of instructional leadership in Israeli principals. School Leadership \& Management, 39(5), 519-536. https://doi.org/10.1080/13632434.2019.1574734

Sindhvad, S., Mikayilova, U., \& Kazimzade, E. (2020). Factors influencing instructional leadership capacity in Baku, Azerbaijan. Educational Management Administration \& Leadership, 1-18. https://doi.org/10.1177/1741143220938364

Syed Imam, S. S. J., \& Ibrahim, M. S. (2010). Cabaran pemimpin novis dalam mengurus sumber manusia bagi melahirkan guru yang kompeten. In Proceedings of the 4th International Conference on Teacher Education; Join Conference UPI \& UPSI Bandung, Indonesia, 2010 (pp. 92-100).

van Knippenberg, D., van Prooijen, J. W., \& Sleebos, E. (2015). Beyond social exchange: Collectivism's moderating role in the relationship between perceived organizational support and organizational citizenship behaviour. European Journal of Work and Organizational Psychology, 24(1), 152-160. https://doi.org/10.1080/1359432X.2013.858699

Victor, A. A. (2017). Analysis of principals' managerial competencies for effective management of school resources in secondary schools in Anambra state, Nigeria. International Journal of Social Sciences, Humanities and Education, 1(4), 1-10.

Vinathan, T. (2016). Hubungan motivasi guru dengan penggunaan ICT dalam pengajaran di SJK (T) daerah Kuala Muda Yan. In Proceedings of the ICECRS (pp. 1043-1054). https://doi.org/10. 21070/picecrs.v1i1.647

Yang, H., van Rijn, M. B., \& Sanders, K. (2020). Perceived organizational support and knowledge sharing: Employees' self-construal matters. International Journal of Human Resource Management, 31(17), 2217-2237. https://doi.org/10.1080/09585192.2018.14439561

Yong, H. H., \& Ku Samsu, K. H. (2019). Sikap negatif guru sebagai penghalang kepada pembentukan perpaduan etnik di sekolah. Akademika, 89(1), 149-159. 